\title{
"Impact of cost stickiness on financial disclosure quality: A study in the Saudi Arabian context"
}

AUTHORS

ARTICLE INFO

RELEASED ON

RECEIVED ON

ACCEPTED ON

LICENSE
Abdulwahid Ahmed Hashed Abdullah (D https://orcid.org/0000-0002-6791-235X

Abdulwahid Ahmed Hashed Abdullah (2020). Impact of cost stickiness on financial disclosure quality: A study in the Saudi Arabian context. Investment Management and Financial Innovations, 17(4), 145-151. doi:10.21511/imfi.17(4).2020.14 http://dx.doi.org/10.21511/imfi.17(4).2020.14

Friday, 27 November 2020

Sunday, 18 October 2020

Thursday, 19 November 2020

\section{$(\mathrm{cc}) \mathbf{E Y}$}

This work is licensed under a Creative Commons Attribution 4.0 International License
JOURNAL

ISSN PRINT

ISSN ONLINE

PUBLISHER

FOUNDER
"Investment Management and Financial Innovations"

$1810-4967$

$1812-9358$

LLC "Consulting Publishing Company "Business Perspectives"

LLC "Consulting Publishing Company "Business Perspectives"
NUMBER OF REFERENCES

29
NUMBER OF FIGURES

0

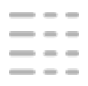

NUMBER OF TABLES

3

(C) The author(s) 2021. This publication is an open access article. 


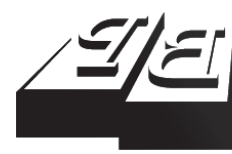

BUSINESS PERSPECTIVES

(O)

LLC "CPC "Business Perspectives" Hryhorii Skovoroda lane, 10, Sumy, 40022, Ukraine www.businessperspectives.org

Received on: $18^{\text {th }}$ of October, 2020 Accepted on: $19^{\text {th }}$ of November, 2020 Published on: $27^{\text {th }}$ of November, 2020

(c) Abdulwahid Ahmed Hashed Abdullah, 2020

Abdulwahid Ahmed Hashed Abdullah, Assistant Professor, Department of Accounting, Prince Sattam Bin Abdulaziz University,Saudi Arabia; Assistant Professor, Department of Accounting, Faculty of Commerce and Economics, Hodeidah University, Yemen.

This is an Open Access article distributed under the terms of the Creative Commons Attribution 4.0 International license, which permits unrestricted re-use, distribution, and reproduction in any medium, provided the original work is properly cited.

Conflict of interest statement Author(s) reported no conflict of interest

\section{IMPACT OF COST STICKINESS ON FINANCIAL DISCLOSURE QUALITY: A STUDY IN THE SAUDI ARABIAN CONTEXT}

\begin{abstract}
The study examines the association between the disclosure quality and cost stickiness in the Saudi Arabian context. The influence of accounting information on the decisions of different stakeholders gives a clear idea of the importance of this accounting information and its reporting. Annual accounting reports form the final stage of the disclosure process. Moreover, the recognition of different types of costs is an important issue in cost and management accounting. Submitting quality annual reports has always been an interesting concern to different stakeholders of a company. The study sample consists of 102 companies listed on the Saudi Stock Exchange Tadawul between 2009 and 2018. The study uses pooled OLS to investigate the association between financial disclosure and cost stickiness. The relationship of financial reporting quality with the cost of goods sold is negative, positive with the sales cost, and positive and insignificant with administrative costs. The study concludes that variables related to sticky costs affect financial quality disclosures. The impact of sticky cost variables on the quality of disclosures is different due to the transition policies adopted by the Saudi Arabian economy.
\end{abstract}

\section{Keywords}

operating cash flow, cost of goods sold, administrative costs, sales cost, Saudi Arabia

JEL Classification M11, M41, M42

\section{INTRODUCTION}

Financial accounting information plays a significant role in various activities of a firm, as well as in the nations' business environment. Financial decisions of a company are based on the information received from the accounting reporting systems and major decisions, such as buying and selling of long-term securities. The influence of accounting information on decisions of different stakeholders gives a clear idea of the importance of this accounting information and its reporting. Annual accounting reports form the final stage of the disclosure process. The process of disclosure of financial information consists of the preparation, reporting, improvement, and use of financial information by different parties in the market. Alternatively, the bound of financial disclosure starts with the execution of reporting standards and ends with the use of these financial disclosures by different users of accounting information. The users of accounting need information useful to them to take significant decisions on time. The significance of financial disclosure depends on the dissemination of quality information that means the way the financial reports reveal the firm's economic position in an acceptable manner. The objective of producing quality reports by a firm is achieved through information transparency, as well as its enhancement and the issuance of annual reports of the best quality. The presentation of quality annual reports has always been an interesting concern to different stakeholders of a 
company. Global accounting communities faced problems of big frauds, and this caused great concern among them regarding the quality of annual reporting. The study of cost behavior in managerial accounting is an important concept for internal and external decisions of a firm, since management accountants and forecast analysts concentrate on the behavior of different costs. Moreover, the recognition of different types of costs is a significant issue in cost and management accounting. There is a change in the behavior of costs due to changes in their drivers. There is a change (increase or decrease) in cost due to a change in the volume of different activities of a firm. The cost can increase or decrease due to a decrease or increase in the volume of the firm's activities, which in accounting terminology is called cost stickiness. The Saudi Organization of Certified Public Accountants (SOCPA) monitors the accounting disclosure practices of different companies in Saudi Arabia. Company Law, Law of Accountancy, and Zakat and Income Tax Law govern the practice of accounting in Saudi Arabia. Moreover, the Saudi listed companies have to report their accounting information under IFRS starting January 1, 2017. In light of this discussion, this study intends to examine the association between the quality of financial disclosures and stickiness of cost in the Saudi Arabian context.

\section{LITERATURE REVIEW}

Cost stickiness is defined as the difference between changes in costs due to changes in the volume of activities that have occurred due to the consumption of different resources. The disproportionate use of the resources of an organization by managers is called a sticky cost behavior that takes place in factory and office costs (Chen et al., 2012; Venieris et al., 2015; Salehi et al., 2018).

The concept of quality of financial reporting is an important phenomenon that has been undertaken currently by accounting professionals. But this financial reporting quality faces huge problems due to fraudulent accounting practices. Managers in an organization adopt different procedures of accounting to verify rather than provide a true image of information, which leads to unfair disclosure of financial information. This is termed in different ways by different researchers (Mathew, 2006; Peter \& Mclaney, 2011).

The term "cost stickiness" refers to cost that increases as sales increase and do not decrease as sales decrease. According to Weiss (2010), an increase in sales revenue by 10 percent leads to an increase in cost by 8 percent, but a decrease in sales revenue by 10 percent leads to a decrease in cost by less than 8 percent. Therefore, the decision about cost stickiness by a manager is an important decision in managing the cost of unconsumed resources. The companies that can bear these additional costs even after a decrease in their sales revenue through resource adjustment costs are efficient, and the opposite is true with the inefficient companies. Different factors lead to cost stickiness in a company, such as an appointment and removal costs of labor, changes in financial activities, sales assumptions, and agency costs (Banker \& Byzalov, 2014; Krishnan et al., 2007; Chen et al., 2012).

Rouxelin et al. (2015) examined the combined cost stickiness in a company filing to assume unemployment rates. They reported that high-cost stickiness leads to a higher prediction rate of unemployment. They suggested that the predictors fail to incorporate full information on cost stickiness from company filings. Arnel (2016) studied the asymmetric behavior of costs due to changes in the volume of activities of industries in the Philippines. The cost behavior was reported using general and administrative expenses and selling expenses. The author reported that firms adjust their costs with a change in market demand (Arnel, 2016). Anderson et al. (2003) examined whether companies had sticky costs. They conduct a comparative study of the dynamics of cost behavior depending on the volume of sales and found sticky costs due to the fact that managers intentionally adjust resources for costs.

Villiers and Zhang (2014) studied the stickiness of audit fees to understand the pricing of audit compared to the audit fee. They found the audit fees were sticky because they did not fully adapt to their features. They also reported a variation between positive and negative adjustments to the audit fee. Ezat (2014) examined the impact of ownership structure and corporate governance on cost stickiness and re- 
ported that board size and its independence reduced the cost stickiness. Mulcahy and Donnelly (2015) studied the impact of reporting of loss on the corporate governance stickiness. They revealed that the loss reported initially would enhance the corporate governance activities, and they also reported that this improvement began before the reporting of this initial loss. Yukcu and Ozkaya (2011), using a sample of Turkish firms, studied the behavior of costs that changes due to changes in the volume of activity. They found a decrease in costs less than the proportionate decrease in sales revenue. The stickiness of cost is highly affected by the stability of macroeconomic factors.

Balakrishnan and Gruca (2008) examined the linear relationship between costs and their related activities. They found the existence of stick costs compared to various types of costs. Understanding organizational features when considering cost behavior is essential. Sepasi and Hassani (2015) examined the impact of firm size and cost stickiness for the firms listed on the Tehran Stock Exchange. They reported that the size of a firm plays a significant role in assessing cost behavior. They also found the cost to be more sticky compared to small firms. Koo et al. (2015) studied the impact of earnings management on cost stickiness. There was a difference in the behavior of costs for suspected and non-suspected earnings. The authors found that the firms with suspected earnings could reduce the stickiness of cost linked this to a manager's decision to cut costs.

Sorros (2013) investigated the impact of cost stickiness on earnings in the international listed firms. The study found that the stickiness of cost affected the earnings in various ways. Malekvar and Abdoli (2015) examined the stickiness of cost in the Tehran Stock Exchange and its impact on corporate governance during the years 2009 and 2012. They reported that the strength of corporate governance positively affected the cost stickiness and reduced it. Ciftci and Salama (2018) investigated the association of cost stickiness and forecast of earnings. They reported a positive association between cost stickiness and earnings management and suggested that firm managers did not include a negative aspect of cost stickiness in the forecasts. Farzaneh et al. (2012) studied the stickiness of different costs to the changes in the sales revenue in firms listed on the Tehran Stock Exchange during the period 2001 to 2010 . They found that the stickiness was not the same for different types of costs compared to changes in sales revenues. They also found that the stickiness of selling and administrative costs was low in the period of reduced sales. Serdaneh (2014) studied the asymmetric behavior of costs for the manufacturing firms listed on the Jordanian Stock Exchange. The study found asymmetric behavior towards selling costs and cost of goods sold; at the same time, it was found that general and administrative costs were symmetric. The cost stickiness model found a high degree of stickiness for high profile companies, while the opposite is true for low profile companies. Financial information, when disseminated with a high-quality aid for making important economic decisions, ultimately leads to financial efficiency (Lambert et al., 2007; Bushman \& Smith, 2013).

\section{METHOD}

This study examines the association between the disclosure quality and cost stickiness in the Saudi Arabian context. In this regard, it uses a linear approach over the 10-year period and can be viewed as a post-event methodology, since the data is historical in nature. The study sample consists of 102 companies listed on Tadawul, a Saudi Arabian stock exchange during the period 2009-2018. The companies chosen for the study are taken from different sectors, such as capital goods, consumer durable, consumer services, energy, food and beverages, health care, materials, retailing, and telecom.

\subsection{Hypotheses}

$H_{0}$ : Cost stickiness does not affect the quality of financial disclosures.

$H_{i}: \quad$ Cost stickiness does affect the quality of financial disclosures.

\subsection{Study variables}

This study uses the quality of financial disclosures (QFD) as a dependent variable. To estimate it, the paper follows previous research studies. Past studies have used forecasted value as the capacity of past profits to forecast future profits (Vincent, 2003; Francis 
et al., 2004, Salehi et al., 2018). The study uses pooled OLS to investigate the association between financial disclosure and cost stickiness. To estimate financial disclosure, the following model has been prepared, as quoted by Salehi et al. (2018).

$$
\begin{aligned}
& \text { Cashflow }_{i t+1}=\alpha_{0}+\beta_{1} \text { Cashflow }_{i t}+ \\
& +\beta_{2} \Delta \text { Acrec }_{i t}+\beta_{3} \Delta \text { Invent }_{i t}+ \\
& +\beta_{4} \Delta \text { Accpay }_{i t}+\beta_{5} \text { Deprec }_{i t}+ \\
& +\beta_{6} \text { Others }_{i t}+\varepsilon_{i t+1},
\end{aligned}
$$

where Cashflow is the flow of cash from operations, $\Delta$ Accrec is the changes in receivables, $\Delta$ Invent is the inventory changes, $\triangle A c c p a y$ is the changes in payables, Deprec is the depreciation on fixed assets, and Others is the outcome of different accruals.

Further, cost stickiness is measured following the approach of Anderson et al. (2003) and Salehi et al. (2018). The explanatory variable, explained as AC, is the administrative cost calculated as the difference between the current year and the previous year divided by the previous years' sales revenue; SC is the sales cost calculated as the difference between the current year and the previous year divided by the previous years' sales revenue; and CGS is the cost of goods sold calculated as the difference between the current year and the previous year divided by the previous years' sales revenue. Moreover, the study also includes some control variables, such as Investment return (RI) calculated as operating income divided by investment; Return on sales (ROS) calculated as operating income divided by revenue on sales; Size is calculated as the logarithm of total assets; Lev is calculated as total assets differentiated by debt and divided by total assets. The model estimated is as follows:

$$
\begin{aligned}
& Q F D_{i t}=\alpha_{0}+\beta_{1} A C_{i t}+\beta_{2} S C_{i t}+ \\
& +\beta_{3} C G S_{i t}+\beta_{4} R I_{i t}+\beta_{5} R O S_{i t}+ \\
& +\beta_{6} S_{i z e_{i t}}+\beta_{7} L e v_{i t}+\varepsilon_{i t} .
\end{aligned}
$$

\section{RESULTS}

This study estimates the impact of cost stickiness on quality of disclosure. This section provides estimated empirical results.

\subsection{Descriptive statistics}

Descriptive statistics of different variables used in the study are reported in Table 1, which allows the data conceptualization. The results show that the dependent variable, i.e. the mean quality of financial disclosure (QFD) is 0 , and the standard deviation is 0.02 . Further, the descriptive results of the independent variables report mean ranging from 0 to 6.14 , while the standard deviation of those variables ranges from 0.04 to 1.32 . Moreover, the results of skewness and kurtosis show that the data used for the analysis is distributed abnormally. Furthermore, autocorrelation and heteroscedasticity are tested using the Durbin - Watson and Breusch - Pagan test statistics. The results show the absence of auto-correlation and the presence of heteroscedasticity. Table 2 provides the results of these test statistics.

\begin{tabular}{|c|c|c|c|}
\hline Variable & Coefficients & $t$-statistics & $p$-value \\
\hline C & 0.0124 & 4.61 & 0.000 \\
\hline$A C$ & 0.0176 & 1.21 & 0.225 \\
\hline SC & 0.0924 & 2.92 & 0.004 \\
\hline CGS & -0.0094 & -1.78 & 0.076 \\
\hline$R I$ & 0.2427 & 15.90 & 0.000 \\
\hline ROS & 0.0421 & 6.64 & 0.000 \\
\hline Size & 0.0031 & 5.09 & 0.000 \\
\hline Lev & -0.0042 & -0.79 & 0.429 \\
\hline \multicolumn{4}{|c|}{ Model diagnostics } \\
\hline F-statistic & $89.97(0.000)$ & & \\
\hline Adj. $R$-square & 0.38 & & \\
\hline
\end{tabular}

\section{Table 1. Descriptive statistics}

\begin{tabular}{l|c|c}
\hline \multicolumn{1}{c|}{ Variable } & Mean & SD \\
\hline QFD & 0.04 & 0.02 \\
\hline AC & 0 & 0.04 \\
\hline SC & 0 & 0.19 \\
\hline CGS & 0 & 0.12 \\
\hline RI & 0.02 & 0.04 \\
\hline ROS & 0.04 & 0.1 \\
\hline Size & 3.14 & 1.32 \\
\hline Lev & 0.43 & 0.14 \\
\hline
\end{tabular}

Table 2. Inferential statistics

\begin{tabular}{c|c:c:c}
\hline Test & $\boldsymbol{t}$-statistic & $\boldsymbol{p}$-value & Result \\
\hline Durbin-Watson test & 2 & 0.0000 & $\begin{array}{c}\text { No } \\
\text { auto-correlation }\end{array}$ \\
Breusch-Pagan test & 4.55 & 0.47 & $\begin{array}{c}\text { Data is } \\
\text { heteroscedastic }\end{array}$ \\
\hline
\end{tabular}

Table 3. Results of the estimated pooled regression model 


\subsection{Regression results}

The pooled regression model results are presented in Table 3. The regression model has an adjusted $R$-Squares of 0.38 , and the estimated model has a $1 \%$ significance level. There is a negative association between the cost of goods sold and financial disclosure quality, significant at the $10 \%$ level. This indicates lower production and selling costs, resulting in poor quality of financial disclosures. The relationship between financial disclosure and administrative cost is insignificant. In addition, there is a positive relationship between the sales cost and financial disclosures, significant at less than $1 \%$.

The result of the control variables shows that the Investment Return (RI) and Return on Sales (ROS) positively affect financial disclosures significant at less than $1 \%$. Further, leverage (Lev) is negatively related to financial disclosures, but is insignificant. Lastly, firm size (Size) is positively associated with financial disclosures, significant at less than $1 \%$.

Moreover, the diagnostic tests are reported in Table 2. The t-statistic of the DW test is 2 and is significant at less than $1 \%$, which shows no auto-correlation, and the test statistic of the Breusch - Pagan test is 4.55 and insignificant, which indicates heteroscedasticity of data.

\section{DISCUSSION}

The relationship between financial disclosure quality and the cost of goods sold is negative and significant. This indicates lower production and selling costs, resulting in poor quality financial disclosures. Saudi Arabian firms are seeking to reduce costs even as the quality of disclosures is deteriorating due to market competition. The insignificant relationship between administrative costs and financial disclosures shows that the former do not affect the quality of disclosures. Also, a positive association between the sales cost and financial disclosures shows that the increase in sales cost leads to an increase in the quality of financial disclosures. The results of this study depart with those of previous research (Brown et al., 2010; Anderson et al., 2003; Chen et al., 2012; Banker \& Byzalov, 2014; DeFond \& Zhang, 2014; Salehi et al., 2018). The results of the control variables help to enhance the quality of financial disclosures. In addition, leverage (Lev) does not have any impact on the financial disclosures, and the relationship between firm size and financial disclosures shows that bigger Saudi Arabian firms report high-quality financial disclosures compared to small firms.

\section{CONCLUSION}

The company's financial decisions are based on information obtained from accounting reporting systems and major decisions such as buying and selling of long-term securities. The financial disclosure process consists of the preparation, reporting, improvement and use of financial information by various parties in the market. The study of cost behavior in managerial accounting is an important concept for internal and external decisions of a firm, since management accountants and forecast analysts concentrate on the behavior of different costs. The study examines the association between the disclosure quality and cost stickiness in the Saudi Arabian context. The study sample consists of 102 companies listed on Tadawul, a Saudi Arabian Stock Exchange, between 2009 to 2018. To investigate the association between financial disclosures and cost stickiness, pooled OLS was used. The study found negative and positive relationships between the quality of financial disclosures and the cost of goods sold versus sales cost, while the administrative cost has no effect on it. Lowering the cost of goods sold can help companies increase their profits, but will reduce the quality of financial disclosures, and the positive impact of sales cost shows that Saudi Arabian managers are investing in sales and marketing to increase profits. Besides, control variables tend to improve the quality of reporting, while leverage does not have any effect. The study as a whole assumes that the variables under consideration explain the impact on the quality of financial disclosures, and this can be further extended by dividing the cost of goods sold by material costs, labor costs and overhead costs. 


\section{AUTHOR CONTRIBUTIONS}

Conceptualization: Abdulwahid Ahmed Hashed Abdullah.

Data curation: Abdulwahid Ahmed Hashed Abdullah.

Formal analysis: Abdulwahid Ahmed Hashed Abdullah.

Investigation: Abdulwahid Ahmed Hashed Abdullah.

Methodology: Abdulwahid Ahmed Hashed Abdullah.

Project administration: Abdulwahid Ahmed Hashed Abdullah.

Supervision: Abdulwahid Ahmed Hashed Abdullah.

Validation: Abdulwahid Ahmed Hashed Abdullah.

Visualization: Abdulwahid Ahmed Hashed Abdullah.

Writing - original draft: Abdulwahid Ahmed Hashed Abdullah.

Writing - review \& editing: Abdulwahid Ahmed Hashed Abdullah.

\section{REFERENCES}

1. Abu-Serdaneh, J. (2014). The Asymmetrical Behavior of Cost: Evidence from Jordan. International Business Research, 7(8), 113-122. https://doi. org/10.5539/ibr.v7n8p113

2. Anderson, M. C., Banker, R. D., \& Janakiraman, S. N. (2003). Are selling, general, and administrative costs 'sticky'? Journal of Accounting Research, 41(1), 47-63. https://doi. org/10.1111/1475-679X.00095

3. Balakrishnan, R., \& Gruca, T. S. (2008). Cost Stickiness and Core Competency: A Note. Contemporary Accounting Research, 25, 993-1006. https://doi. org/10.1506/car.25.4.2

4. Banker, R., \& Byzalov, D. (2014). Asymmetric cost behavior. Journal of Management Accounting Research, 26(2), 43-79. https://doi. org/10.2308/jmar-50846

5. Banker, R. D., Basu, B., Byzalov, D., \& Chen, J. Y. S. (2016). The confounding effect of cost stickiness on conservatism estimates. Journal of Accounting and Economics, 61(1), 203-220. https://doi.org/10.1016/j.jacceco.2015.07.001

6. Brown, J., Falaschetti, D., \& Orlando, M. (2010). Auditor independence and earnings quality: evidence for market discipline vs. Sarbanes-Oxley proscriptions. American Law and Economics Review, 12(1),
39-68. https://doi.org/10.2139/ ssrn. 940847

7. Bushman, R., \& Smith, A. (2001). Financial accounting information and corporate governance. Journal of Accounting and Economics, 32(1-3), 237-333. https://doi.org/10.1016/S01654101(01)00027-1

8. Ciftci, M., \& Salama, F. M. (2018). Stickiness in Costs and Voluntary Disclosures: Evidence from Management Earnings Forecasts. Journal of Management Accounting Research, 30(3), 211-234. https:// doi.org/10.2308/jmar-51966

9. Chen, C.X., Lu, H., \& Sougiannis, T. (2012). The agency problem, corporate governance, and the asymmetrical behavior of selling, general, and administrative costs. Contemporary Accounting Research, 29(1), 252-282. https://doi.org/10.1111/j.19113846.2011.01094.X_

10. DeFond, M., \& Zhang, J. (2014). A review of archival auditing research. Journal of Accounting and Economics, 58(2-3), 275-326. https://doi.org/10.1016/j.jacceco.2014.09.002

11. Ezat, A. N. M. (2014). Corporate Governance Ownership Structure and Cost Stickiness: Evidence from Egypt. The Egyptian Journal of Commercial Studies, 38(4), 27-78. Retrieved from https://www.researchgate.net/ publication/283854985_Cor-
porate_Governance_Ownership_Structure_and_Cost_Stickiness_Evidence_from_Egypt

12. Farzaneh, N., Javad, S. M., Mahdi, S., \& Haddad, B. S. A. (2013). A Study of The Stickiness of Cost Of Goods Sold And Operating Costs To Changes In Sales Level In Iran. Studies in Business and Economics, 8(2), 79-89. Retrieved from https://ideas.repec.org/a/blg/ journl/v8y2013i2p79-89.html

13. Francis, J., LaFond, R., Olsson, P., \& Schipper, K. (2004). Costs of equity and earnings attributes. The Accounting Review, 79(4), 967-1010. https://doi.org/10.2308/ accr.2004.79.4.967

14. Koo, J. H., Song, S., \& Paik, T. Y. (2015). Earning Management and Cost Stickiness. Advanced Science and Technology Letters, 84, 40-44.

15. Krishnan, J., Raghunandan, K., \& Yang, J. (2007). Were former Andersen clients treated more leniently than other clients? Evidence from going-concern modified audit opinions. Accounting Horizons, 21(4), 423435. https://doi.org/10.2308/ acch.2007.21.4.423

16. Lambert, R., Leuz, C., \& Verrecchia, R. (2007). Accounting information disclosure, and the cost of capital. Journal of Accounting Research, 45(2), 385-420. https://doi.org/10.1111/ j.1475-679X.2007.00238.x 
17. Malekvar, H., \& Abdoli, M. (2015). Relationship between Costs Stickiness and Corporate Governance. Bulletin of the Gregorian National Academy of Sciences, 9(2), 191-196. Retrieved from https://www.researchgate. net/publication/328390801_The relationship_between_cost_stickiness_and_financial_reporting_quality_in_Tehran_Stock_Exchange

18. Mathew, R. (2006). Accounting Theory and Development. PrenticeHall.

19. Mulcahy, M., \& Donnelly, R. (2015). Corporate governance, stickiness, and losses. Corporate Governance, 15(3), 391-408. https://doi.org/10.1108/CG-112013-0117

20. Peter, A., \& Mclaney, J. (2011) Financial Accounting for Decision Makers. Amazon Publishing. Retrieved from https://www. amazon.com/Financial-Accounting-Decision-Makers-8th/ dp/1292099046

21. Rouxelin, F., Wongsunwai, W., \& Yehuda, N. (2018). Aggregate Cost Stickiness in GAAP Financial Statements and Future Unemployment Rate. The Accounting Review, 93(3), 299-325. https://doi.org/10.2308/accr51939
22. Salehi, M., Ziba, N., \& Gah, A. D. (2018). The relationship between cost stickiness and financial reporting quality in Tehran Stock Exchange. International Journal of Productivity and Performance Management, 67(9), 1550-

1565. https://doi.org/10.1108/ IJPPM-10-2017-0255

23. Sepasi, S., \& Hassani, H. (2015). Study of the Effect of the Firm Size on Costs Stickiness: Evidence from Tehran Stock Exchange. IJABER, 13(6), 4143-4159. Retrieved from https://www.researchgate.net/ publication/301681172_Study_of the_effect_of_the_firm_size_on_ costs_stickiness_Evidence_from_ Tehran_stock_exchange

24. Sorros, J. (2013). The Effect of Manufacturing Cost and SGA Cost to Earnings: Evidence from International Listed Firms (3rd ed.). Annual International Conference on Accounting and Finance.

25. Suleyman, Y., \& Hakan, O. (2011). Cost Behavior in Turkish Firms: Are Selling, General and Administrative Costs and Total Operating Costs "Sticky"? World of Accounting Science, 13(3), 1-27. Retrieved from https:// web.b.ebscohost.com/abstract?direct $=$ true $\&$ profile $=$ ehost $\&$ scope $=$ si te\&authtype $=$ crawler\&jrnl $=130225$ $8 X \& A N=67068119 \& \mathrm{~h}=\mathrm{r} 3 \mathrm{maZXJh}$ Z6xP4cbbEK8xxRlnTRjBpM4hfQl
WOnkehEE2Xk5qy9zxs4XvZGf61 AmBm\%2fX0HOrF1h4K0\%2bdNz U8IAA $\% 3 \mathrm{~d} \% 3 \mathrm{~d} \& \mathrm{crl}=\mathrm{c} \&$ resultNs= AdminWebAuth\&resultLocal=Err CrlNotAuth\&crlhashurl=login.asp $\mathrm{x} \% 3$ fdirect\%3dtrue\%26profile\%3d ehost $\% 26$ scope $\% 3$ dsite\%26authtyp e\%3dcrawler\%26jrnl\%3d1302258X \%26AN\%3d67068119

26. Uy, A. O. O. (2016). Analyzing cost behavior of the Philippine Industrial Firms. Academy of Accounting and Financial Studies Journal, 20(1), 103-114. Retrieved from https://www.researchgate. net/publication/310487651_Analyzing_cost_behavior_of_Philippine_industrial_firms

27. Venieris, G., Naoum, V., \& Vlismas, O. (2015). Organization capital and sticky behavior of selling, general, and administrative expenses. Management Accounting Research, 26, 45-82. https://doi.org/10.1016/j. mar.2014.10.003

28. Villiers, C., Hay, D., \& Zhang, Z. (2013). Audit fee stickiness. Managerial Auditing Journal, 29(1), 2-26. https://doi.org/10.1108/ MAJ-08-2013-0915

29. Weiss, D. (2010). Cost Behavior and Analysts' Earnings Forecasts. The Accounting Review, 85(4), 1141-1471. https://doi. org/10.2308/accr.2010.85.4.1441 